\title{
Sistem Kendali Dan Pengawasan Wilayah Pintu Berbasis IoT
}

\author{
Arnes Sembiring ${ }^{1}$, Mardiana $^{2}$, Muhammad Rizki Ramadhan ${ }^{3}$ \\ ${ }^{1,2,3}$ Teknik Informatika Universitas Harapan Medan \\ Jl. H.M. Joni No. 70C Medan \\ arnessembiringagmail.com
}

\begin{abstract}
Abstrak - Dalam penelitian ini, diajukan sebuah sistem pengamanan pintu berbasis IoT yang memfasilitasi pemilik rumah untuk membuka dan menutup pintu serta mengunci dan membuka kunci pintu melalui jaringan internet. Sistem ini juga dilengkapi dengan fitur real time video streaming sehingga pemilik dapat mengamati lingkungan di sekitar pintu dan memastikan orang yang ada di depan pintu sebelum membukanya. Raspberry Pi digunakan sebagai pengendali utama sistem yang menyediakan halaman web bagi pengguna dan pemberi sinyal kendali ke board Arduino Uno. Arduino Uno mengendalikan servo untuk kendali pintu. Kamera yang digunakan dalam penelitian ini adalah Raspberry Camera dengan resolusi 5 MP. Dari hasil pengujian yang dilakukan, diperolah hasil bahwa sistem yang telah diwujudkan dapat bekerja dengan baik. Kendali servo berkerja sebagaimana yang diharapkan dan respon servo terhadap perubahan masukan pengguna di halaman web juga cukup cepat. Video streaming berjalan lancar pada 30 fps dengan resolusi 640x480.
\end{abstract}

Keywords - Raspberry Pi, Video Streaming, Internet of Things, Kendali Pintu

\section{PENDAHULUAN}

Perkembangan teknologi mikrokontroler dan internet telah menghasilkan teknologi kendali berbasis internet dengan harga perangkat yang cukup terjangkau. Hal ini telah mendorong munculnya banyak penelitian dalam bidang sistem kendali berbasis internet atau biasa disebut Internet of Things (IoT). Sebagian peneliti menggunakan board Arduino Uno yang dihubungkan ke jaringan internet via gelombang Wifi menggunakan ESP8266. Sebagian mengunakan mikrokontroler Raspberry Pi atau Orange Pi.

Salah satu penelitian sistem kendali berbasis IoT yang cukup banyak diteliti adalah sistem pengamanan rumah berbasis Internet of Thing. Keuntungan dari sistem ini adalah pemilik rumah memiliki akses ke sebuah atau beberapa perangkat di rumah melalui jaringan internet sehingga perangkat tersebut dapat diakses dari mana saja. Tentu fitur seperti ini akan meningkatkan aspek keamanan rumah tersebut sekaligus meningkatkan rasa aman dan ketenangan bagi pemilik rumah sendiri. Lebih dari itu, kemudahan mengendalikan sebagian perangkat di rumah juga akan memudahkan berbagai urusan tanpa harus datang ke rumah, bahkan dapat dilakukan dari mana saja selama terkoneksi ke jaringan internet.

Pada penelitian yang dilakukan oleh Arafat yang membuat sistem pengamanan pintu otomatis rumah berbasis Internet of Things (IoT) dengan ESP8266 dan menggunakan aplikasi Blynk, Reed sensor, dan selenoid lock yang menciptakan sistem pengunci dan pembuka pintu otomatis yang mampu dikendalikan oleh aplikasi android yang telah disesuaikan sebagai metode kontrol akses [1].

Dalam penelitian ini, diajukan sebuah sistem pengamanan pintu berbasis IoT yang dilengkapi dengan fitur real time video streaming sehingga pemilik dapat mengamati lingkungan di sekitar pintu dan memastikan orang yang ada di depan pintu sebelum membukanya melalui jaringan internet. Video streaming ini ditampilkan di satu halaman web bersama dengan tampilan kendali buka/tutup dan kunci pintu bagi pemilik.

Sistem yang diajukan ini terdiri dari mikrokontroler Raspberrry Pi 3 sebagai pengendali utama, Raspberrry Pi camera untuk mengambil gambar untuk video streaming, dua buah motor servo untuk proses buka/tutup dan kunci pintu, dan Arduino Uno untuk menangani pengendalian kedua motor servo. Sementara perangkat lunak yang digunakan adalah sistem operasi Raspbian Jessie untuk menggerakkan mikrokontroler Raspberrry Pi dan MJPEG Streamer untuk menyediakan layanan video streaming. Halaman web dibangun menggunakan HTML dan CGI (Common Gateway Interface) menjembatani komunikasi antara halaman web dengan Raspbian untuk kendali pin-pin GPIO pada mikrokontroler Raspberrry Pi.

\section{STUDI LITERATUR}

\section{A. Raspberry Pi}

Raspberry pi adalah komputer berukuran kartu kredit yang awalnya dirancang untuk pendidikan, terinspirasi oleh 1981 BBC micro. Tujuannya adalah menciptakan perangkat berbiaya rendah yang akan meningkatkan keterampilan pemrograman dan pemahaman perangkat keras di tingkat prauniversitas. Namun berkat ukurannya yang kecil dan harga yang dapat diakses, perangkat ini diadopsi dengan cepat oleh para penggemar elektronik untuk proyek yang memerlukan lebih dari mikrokontroler dasar (seperti perangkat Arduino [2].

Terdapat beberapa model raspberry pi yang sudah diproduksi dan dijual di pasaran antara lain adalah Raspberry Pi 3 model B, Raspberry Pi 2 model B, 
Raspberry Pi Zero, Raspberry Pi 1 Model B+ dan Model A+ [3].

Kelebihan utama Raspberry Pi adalah dapat melakukan segala hal yang dapat dilakukan oleh komputer/laptop dengan sistem operasi Linux karena Raspberry Pi menggunakan salah satu distro Linux yaitu Raspbian. Karenanya Rapberry Pi digunakan untuk membuat server dan membuat program dengan berbagai macam bahasa tingkat tinggi terutama Python. Dan untuk penyimpanan data, Raspberry pi tidak menggunakan Hard disk namun menggunakan SD Card untuk menyimpan data, baik itu data operating system ataupun untuk media penyimpanan data jangka panjang.

Karena Raspberry Pi menggunakan sistem operasi sebagaimana komputer pada umumnya, Raspberry pi mungkin akan sedikit lebih lambat dalam merespon beberapa tugas tertentu bila dibandingkan dengan mikrokontroler lain yang lebih ringkas seperti Arduino Uno karena kernel Linux pada sistem operasi Raspbian memiliki fungsi prioritas proses seperti yang dimiliki oleh semua sistem operasi. Penggunaan Rapberry Pi pada kendali lengan menggunakan motor servo atau sistem kendali lain yang menggunakan sinyal PWM kadang berjalan lebih lambat dan memerlukan perlakuan khusus. Oleh karena itu, dalam penelitian ini digunakan Arduino Uno sebagai pengendali langsung motor servo.

\section{B. MJPEG Streamer}

Pada penelitian ini, MJPEG Streamer digunakan sebagai pemroses media citra yang diambil oleh kemera Raspberry Pi untuk ditayangkan sebagai video streaming di sisi pengguna.

MJPEG Streamer adalah aplikasi yang menyalin beberapa citra JPEG dari satu atau beberapa input plugin ke beberapa output plugin. Cara ini digunakan untuk mewujudkan video streaming dari serangkaian citra JPEG melalui jaringan berbasis IP dari kamera ke berbagai jenis browser penerima seperti Chrome, Firefox dan perangkat lunak lain yang mampu menerima aliran MJPEG.

Pada awalnya MJPEG Streamer ditulis untuk perangkat terbenam (embedded system) yang memiliki sumber daya yang sangat terbatas (terutama sisi memori RAM dan kemampuan proses CPU). Versi pendahulunya uvc_streamer dibuat karena kamera yang kompatibel dengan Linux-UVC secara langsung menghasilkan JPEG data sehingga memungkinkan aliran data MJPEG yang cepat dan handal [4].

\section{CGI (Ccommon Gateway Interface)}

Common Gateway Interface (CGI) adalah suatu standar untuk menghubungkan berbagai program aplikasi ke halaman web. CGI mirip sebuah program komputer yang menjadi perantara antara standar
HTML yang menjadikan tampilan web dengan program lain. Hasil yang diperoleh dari proses pencarian dikirimkan kembali ke halaman web untuk ditampilkan dalam format HTML.

CGI juga dapat berjalan pada berbagai platform web server yang ada di world wide web. Selain itu CGI mempunyai beberapa kekurangan, CGI mempunyai beberapa isu keamanan. Dengan menggunakan CGI akan membuat seseorang dapat menjalankan program pada server. Oleh karena itu program yang menggunakan CGI harus dipisahkan pada directory tertentu, sehingga seseorang tidak dapat menjalankan program menggunakan CGI diluar directory tersebut [5].

\section{DESAIN SISTEM}

\section{A. Blok Diagram Sistem}

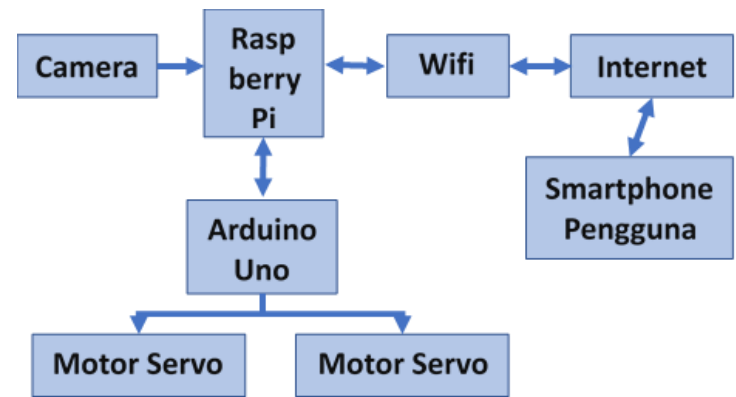

Gbr. 1 Blok Diagram Sistem

Berdasarkan gambar 1, Raspberry Pi bertindak sebagai pengendali utama sistem. Camera berfungsi sebagai pemantau (alat penangkap citra pengamatan). Citra yang diambil kamera yang akan dialirkan sebagai video streaming oleh MJPEG Streamer yang terinstal pada sistem operasi Raspbian pada Raspberrry Pi. Arduino Uno berfungsi sebagai pengendali motor servo dan kedua motor servo berfungsi sebagai penggerak mekanis pembuka/penutup pintu dan buka/kunci pintu. Raspberry Pi terhubung dengan internet melalui jaringan Wifi. Selanjutnya pengguna dapat mengakses sistem secara online melalui smartphone (atau bisa juga PC) untuk membuka halaman web pengguna menggunakan sembarang browser. Dalam halaman web pengguna itu, pengguna dapat melihat secara real time keadaan di sekitar pintu, memverifikasi secara langsung siapa yang berada di depan pintu dan mengendalikan pintu seperti membuka, menutup, mengunci dan membuka kunci pintu.

Pada penelitian ini, komunikasi antara halaman HTML dengan pin-pin GPIO Raspberry Pi dijembatani oleh CGI seperti ditunjukkan pada gambar 2. Hal ini dapat mengurangi kesulitan pengendalian nilai-nilai keluaran dari pin-pin GPIO ataupun 
membaca nilai masukannya karena HTML tidak memiliki akses terhadap pin-pin GPIO. Pengendalian nilai keluaran dari pin-pin GPIO dilakukan oleh CGI sedangkan halaman HTML mengakses CGI yang diperlukan untuk nilai keluaran pin GPIO yang dikehendaki.

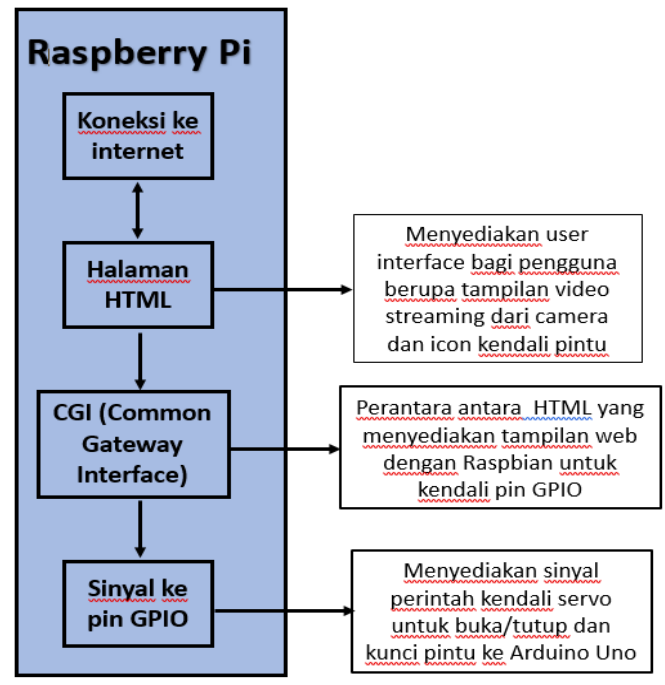

Gbr. 2 Blok Diagram Perangkat Lunak pada Raspberry Pi

\section{B. Rangkaian Sistem}

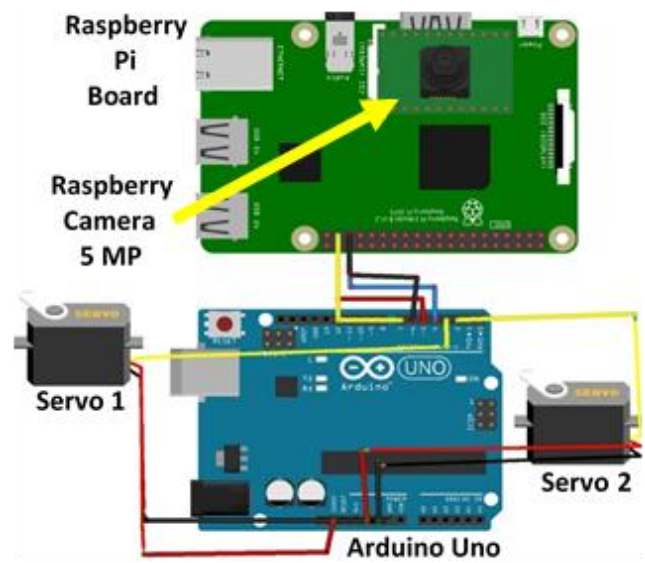

Gbr. 3 Diagram Skematik Sistem

Pada rangkaian skematik di gambar 3, camera dipasang langsung ke camera port pada board Raspberry Pi karena pada penelitian ini kamera yang digunakan adalah Raspberry Pi Camera dengan resolusi $5 \mathrm{MP}$, bukan kamera jenis webcam yang biasa dihubungkan melalui USB port. Koneksi ke internet melalui jaringan Wifi menggunakan antena Wifi yang sudah terintegrasi pada board Raspberry Pi 3.

Pengendalian motor servo 1 dan servo 2 dilakukan oleh Arduino Uno. Perintah kendali berasal dari Raspberry Pi melalui koneksi 4 kabel. Koneksi ini tidak menggunakan protokol komunikasi khusus, cukup Raspberry Pi mengeluarkan sinyal di 4 buah pin yang terkoneksi ke Arduino Uno dan Arduino Uno membaca nilai keempat sinyal secara rutin. GPIO 19 dan GPIO 16 Raspberry Pi mengeluarkan sinyal kendali untuk servo 1 (buka/tutup pintu) sementara GPIO 26 dan GPIO 20 untuk servo 2 (kunci/buka kunci pintu).

Untuk mengendalikan proses buka/tutup pintu dan kunci/buka kunci pintu digunakan dua buah motor servo. Motor servo menggunakan sinyal PWM untuk pengaturan derajat perpindahan sudutnya. Sebagaimana telah ditinjau sebelumnya, terdapat kemungkinan penggunaan kendali perangkat menggunakan sinyal PWM mengalami keterlambatan eksekusi karena efek dari fungsi prioritas proses pada kernel Linux sistem operasi Raspbian. Oleh karena itu, dalam penelitian ini digunakan board Arduino Uno sebagai penyedia sinyal PWM untuk kendali gerak servo untuk mendapatkan posisi dan waktu yang akurat.

\section{IV.HASIL DAN PEMBAHASAN}

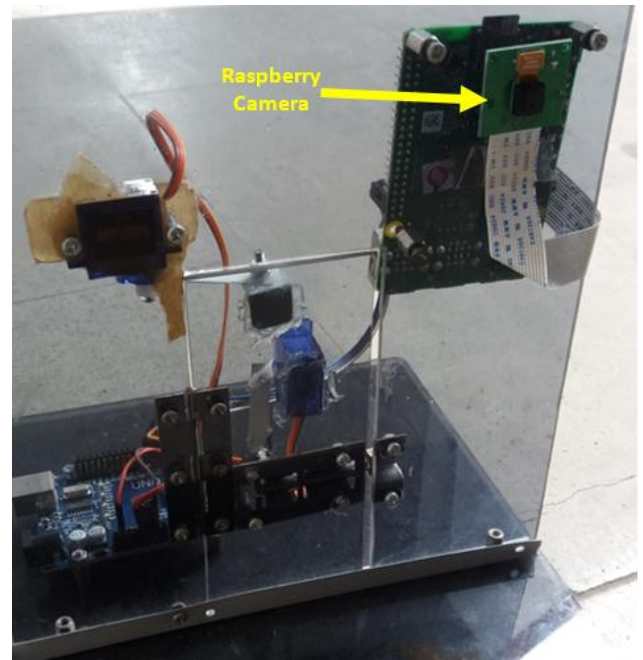

Gbr. 5 Implementsai Sistem Bagian Luar Rumah

Gambar 4 dan 5 menunjukkan implementasi rangkaian yang telah dibahas sebelumnya. Sistem diwujudkan dalam bentuk prototype yang dibangun menggunakan material akrilik. Raspberry Pi, servo 1, servo 2 dan Arduino Uno diletakkan di sebelah dalam dinding (rumah) seperti pada gambar 3 dan kamera dipasang di atas pintu sebelah luar dinding seperti pada gambar 5 untuk mendapatkan pengamatan jelas dari wilayah sekitar pintu. Seluruh sistem ditenagai oleh sistem catu daya $5 \mathrm{~V} 3 \mathrm{~A}$

Koneksi yang lancar ke internet diperlukan agar sistem dapat berjalan dengan baik dan pengguna (pemilik rumah) dapat mengakses halaman web pengguna dari mana saja selama sistem di rumah sudah terhubung ke internet dan pengguna juga terhubung ke internet. 


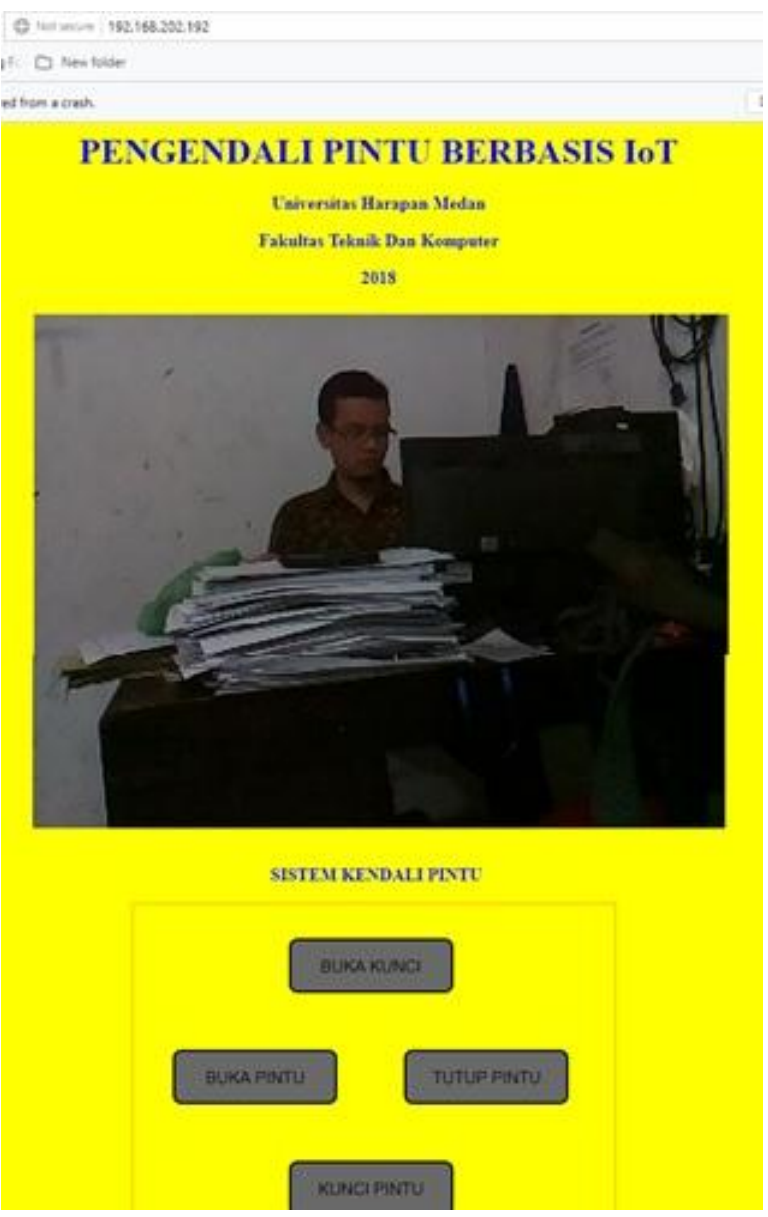

Gbr. 6 Tampilan Halaman Web Pengguna

Gambar 6 menunjukkan tampilan kendali pengguna. Setelah judul dari halaman web pengguna, terdapat tampilan video streaming dari wilayah di depan pintu yang dapat dijangkau oleh kamera. Di bawah tampilan video streaming, terdapat 4 button yang dapat digunakan oleh pengguna untuk mengendalikan buka dan tutup pintu serta mengunci atau membuka kunci. Setiap pengguna mengklik button yang tersedia, sistem akan menanggapi sesuai dengan operasi yang dikehendaki.

Tabel I merupakan tabulasi terhadap hasil pengujian sistem kendali pintu. Dari pengujian yang dilakukan, diperoleh hasil yang baik dan sesuai dengan yang direncanakan. Kelancaran video streaming memang sangat tergantung pada kelancaran jaringan internet yang digunakan,
TABEL I

HASIL PENGUJIAN SISTEM

\begin{tabular}{|l|l|l|l|}
\hline No & \multicolumn{1}{|c|}{ Pengujian } & \multicolumn{1}{|c|}{ Respon sistem } & \multicolumn{1}{|c|}{ Keterangan } \\
\hline 1. & $\begin{array}{l}\text { Tombol buka } \\
\text { kunci ditekan }\end{array}$ & $\begin{array}{l}\text { Servo 2 buka } \\
\text { kunci }\end{array}$ & $\begin{array}{l}\text { Respon sesuai } \\
\text { yang diharapkan }\end{array}$ \\
\hline 2. & $\begin{array}{l}\text { Tombol buka } \\
\text { pintu ditekan }\end{array}$ & $\begin{array}{l}\text { Servo 1 buka } \\
\text { pintu }\end{array}$ & $\begin{array}{l}\text { Respon sesuai } \\
\text { yang diharapkan }\end{array}$ \\
\hline 3. & $\begin{array}{l}\text { Tombol tutup } \\
\text { pintu di tekan }\end{array}$ & $\begin{array}{l}\text { Servo 1 tutup } \\
\text { pintu }\end{array}$ & $\begin{array}{l}\text { Respon sesuai } \\
\text { yang diharapkan }\end{array}$ \\
\hline 4. & $\begin{array}{l}\text { Tombol kunci } \\
\text { pintu ditekan }\end{array}$ & $\begin{array}{l}\text { Servo 2 kunci } \\
\text { pintu }\end{array}$ & $\begin{array}{l}\text { Respon sesuai } \\
\text { yang diharapkan }\end{array}$ \\
\hline 5 & $\begin{array}{l}\text { Aliran data } \\
\text { video } \\
\text { streaming pada } \\
\text { 30 fps dengan } \\
\text { resolusi } \\
\text { 640x480 }\end{array}$ & $\begin{array}{l}\text { cukup jelas pada } \\
\text { pencahayaan baik } \\
\text { dan jaringan } \\
\text { internet dengan } \\
\text { bantwidth yang } \\
\text { cukup }\end{array}$ & $\begin{array}{l}\text { Hasil sesuai } \\
\text { dengan yang } \\
\text { diharapkan } \\
\text { namun } \\
\text { tergantung pada } \\
\text { jaringan yang } \\
\text { ada. }\end{array}$ \\
\hline
\end{tabular}

\section{KESIMPULAN}

Dari hasil pengujian sebelumnya, diperoleh hasil yang cukup baik. Sistem dapat berjalan sebagaimana ynag diharapkan. Aliran data pada video streaming juga cukup lancar. Sistem dapat dengan cepat menggapi setiap perintah pengguna untuk membuka/menutup pintu serta mengunci dan membuka kunci pintu.

\section{UCAPAN TERIMA KASIH}

Ucapan terima kasih untuk Universitas Harapan Medan khususnya Laboratorium Robotika dan Sistem Cerdas Program Studi Teknik Informatika Universitas Harapan Medan yang telah menyediakan sumber daya penelitian termasuk sebagai tempat pengujian implementasi sistem.

\section{REFERENSI}

[1] Arafat, "Sistem Pengamanan Pintu Rumah Berbasis Internet Of Things (IoT) Dengan ESP8266," Jurnal Ilmiah Technologia Vol. 7, no. 4, 2016

[2] opensource.com [Online]. Available: https://opensource.com/resources/raspberry-pi.

[3] M. Angga, Perbedaan Raspberry [Online]. Available: https://news.ralali.com/apa-ituraspberry-pi/

[4] Jacksonliam, mjpg-streamer, [Online]. Available: https://github.com/jacksonliam/mjpg-streamer

[5] A. F. Harismawan, A. P. Kharisma, and T. Afirianto Analisis Perbandingan Performa Web Service Menggunakan Bahasa Pemrograman Python , PHP , dan Perl pada Client Berbasis Android, Jurnal Pengembangan Teknologi Informasi dan Ilmu Komputer, vol. 2, no. 1, p. 237-245, 2017 